\title{
Reactividad del cemento aluminoso en agua: Caracterización de la fase acuosa de los poros y de la fase sólida
}

\author{
Reactivity of high alumina cement in water: \\ Pore solution and solid phase characterization
}

\begin{abstract}
RESUMEN
La reacción de hidratación del cemento aluminoso (CA), a la temperatura de $20^{\circ} \mathrm{C}$ y relación agua/cemento de 0,5 , ha sido estudiada durante un mes. Los cambios de la fase sólida se siguieron por difracción de rayos $X$ y análisis térmico. Además, la fase acuosa de los poros (FAP) fue extraída mediante aplicación de altas presiones mecánicas (500 MPa) en diferentes etapas de la reacción, con el fin de estudiar la evolución de su composición química durante el proceso de hidratación.

Fecha de recepción: 18-XI-92
\end{abstract}

\author{
M." T. GAZTAÑAGA, S. GOÑI (*) y J. L. SAGRERA \\ ICCET/CSIC \\ ESPAÑA
}

\begin{abstract}
$S U M M A R Y$
The hydration reaction of high alumina cement at a temperature of $20^{\circ} \mathrm{C}$ and water/cement ratio of 0.5 has been studied over a period of one month. The changes of the solid phase were followed by $X$-ray diffraction and thermal analysis. Besides, pore-solution was expressed by application of high mechanical pressure (500 MPa) during different periods of the reaction in order to study its chemical composition evolution as a result of the hydration process.
\end{abstract}

\section{PALABRAS CLAVE}

FASE ACUOSA DE LOS POROS, CEMENTO ALUMINOSO, REACCIÓN DE HIDRATACIÓN, COMPOSICIÓN QUÍMICA.

\section{INTRODUCCIÓN}

Durante la reacción de hidratación del cemento anhidro se desarrolla una matriz compleja y heterogénea que está formada por diferentes hidratos sólidos y una fase acuosa. Esta fase acuosa, que aparece como resultado del exceso de agua empleada en el amasado, juega un importante papel tanto desde el punto de vista de la durabilidad del material hidratado como de las

\section{KEY WORDS}

PORE-SOLUTION, HIGH ALUMINA CEMENT (HAC), HYDRATION REACTION, CHEMICAL COMPOSITION.

\section{INTRODUCTION}

During the hydration reaction of anhydrous cement a very complex and heterogeneous matrix develops which is formed by different solid hydrated as well as aqueous phase. This aqueous phase, which appears as a result of the excess of water employed for mixing, plays an important role from the point of view of the durability of both the hydrated material itself and metallic

$\left(^{\star}\right)$ Autor con quien debe establecerse la correspondencia.

(1) Contribución técnica presentada en el 12th International Symposium on the Reactivity of Solids 
armaduras metálicas. La composición de la FAP regula, a edades cortas, el período cinético anterior al fraguado, así como los primitivos núcleos de los precipitados. A edades posteriores, se produce una continua interdependencia entre la solución contenida en la microestructura porosa y la nueva matriz sólida hidratada, a través de los diferentes equilibrios que se establecen entre ellas. Cualquier cambio de la composición química de la FAP, provocado por agresivos internos o externos, tendrá repercusiones en el sólido; por lo tanto, la información sobre dichos cambios de la composición de la FAP será de gran importancia en el estudio del posible proceso de degradación del material durante su período de vida útil.

La composición de la FAP y su evolución con el avance de la reacción de hidratación, son bien conocidos en el caso del cemento portland ordinario (CPO). En el caso del CA, la matriz que se desarrolla como resultado de la reacción de hidratación, es mucho más compleja debido a los diferentes aluminatos hidratados que se pueden formar. Problemas relacionados con la conversión de estos aluminatos y su repercusión en la pérdida de resistencia mecánica de la matriz se han estudiado ampliamente (1-8), así como los mecanismos de las reacciones de hidratación y la composición de la solución a edades tempranas (9-18), pero no se han encontrado trabajos relacionados con su composición una vez que el material ha endurecido.

La finalidad de este trabajo es determinar la evolución de las fases sólida y acuosa como resultado de la reacción de hidratación durante un período de 30 días.

\section{EXPERIMENTAL}

Se ha empleado un cemento aluminoso fundido español, de tipo comercial, que ha sido suministrado por cementos Molins y cuya composición química se da en la tabla 1 .

Se prepararon pastas de cemento con una relación agua/cemento de 0,5 usando agua destilada. Esta pasta se introdujo en cilindros de plástico sellados que fueron almacenados en unas condiciones de $100 \%$ de $\mathrm{HR}$ y $20^{\circ} \mathrm{C}$ de temperatura durante diferentes períodos hasta reinforcements. The composition of the solution regulates at early ages the kinetic period before setting as well as the primitive nuclei of precipitates. At later ages a continuous interdependence between the solution contained in the porous microstructure and the new hydrated solid matrix is produced through the equilibria established between them. Any change of the chemical composition of the pore-solution provoked by either external or internal aggressives will have repercussions on the solid, therefore information on changes in pore-solution composition over time will be of a great significance in studying the possible degradation process of the material during its useful life period.

The composition of the pore-solution and its evolution as hydration reaction advances is well known in the case of ordinary portland cement (OPC). In the case of high alumina cement (HAC) the matrix developed as a result of the hydration reaction is much more complex due to the different hydrated aluminate which may form. Problems related to the conversion of those aluminates and its repercussion on the loss of mechanical strength of the matrix have been widely studied [1-8] as well as the hydration reaction mechanisms have been studied from the composition of solution at earlier ages [9-18], but no works have been found related to the expressed pore-solution composition, once the material has hardened.

The aim of this paper is to determine the evolution of both aqueous and solid phases as a result of the HAC hydration reaction during a period of 30 days from mixing.

\section{EXPERIMENTAL}

A Spanish commercial Fondu High Alumina Cement (HAC) supplied by Cements Molins has been used which chemical composition is given in table 1.

Pastes of water/cement ratio 0.5 were prepared with distilled water and cast into sealed plastic cylinders which were stored at $100 \%$ RH and $20^{\circ} \mathrm{C}$ for different periods up to 30 days. After three hours from mixing the samples were cooled in ice during 12 hours to avoid the heating

TABLA 1 TABLE 1

Composición Química del Cemento

(Chemical Composition of the High Alumina Cement)

\begin{tabular}{|c|c|c|c|c|c|c|c|c|}
\hline $\mathrm{SiO}_{2}$ & $\mathrm{Fe}_{2} \mathrm{O}_{3}$ & $\mathrm{Al}_{2} \mathrm{O}_{3}$ & $\mathrm{CaO}$ & $\mathrm{MgO}$ & $\mathrm{S}$ & $\mathrm{Na}_{2} \mathrm{O}$ & $\mathrm{K}_{2} \mathrm{O}$ & $\mathrm{IL}$ \\
\hline 2.74 & 14.24 & 43.49 & 38.51 & 0.44 & 0.03 & 0.046 & 0.082 & - \\
\hline
\end{tabular}


30 días. Las muestras se enfriaron en hielo durante doce horas para evitar el calentamiento producido por la reacción de hidratación fuertemente exotérmica. Antes del fraguado (hasta 3 horas), se extrajo la solución por medio de centrifugación y filtración de las muestras en una atmósfera de $\mathrm{N}_{2}$, para evitar la carbonatación atmosférica. A partir de un día, la FAP fue extraida empleando un aparato similar al descrito previamente (19, 20), y la presión mecánica fue aplicada gradualmente hasta alcanzar un vaior máximo de $500 \mathrm{MPa}$.

Las concentraciones de sodio y potasio se determinaron por espectroscopía de absorción atómica con un equipo Perkin Elmer 305, y las correspondientes al calcio y aluminio se hicieron por espectrocopía de emisión con plasma acoplado inductivamente (ICP), empleando un equipo Yobin Ybon 38 VHR. El pH se midió con un electrodo combinado de rango de $\mathrm{pH}$ entre $0-14$. Las medidas de concentración de $\mathrm{OH}^{-}$no se pudieron realizar debido a la interferencia de un precipitado de hidróxido de aluminio que aparecía durante la valoración ácido-base. Por lo tanto, los valores que aparecen en el texto no son concentraciones sino actividades calculadas a partir del $\mathrm{pH}$.

Los difractogramas de rayos $X$ se realizaron con un difractómetro de la casa Philips PW 1730, monocromador de grafito y radiación $\mathrm{CuK} \alpha_{1}$. Los análisis térmicos (TG y ATD) se hicieron con un equipo Mettler TA-1. El peso de las muestras fue de $300 \mathrm{mg}$; se empleó una velocidad de calentamiento de $4^{\circ} \mathrm{C} / \mathrm{min}$. en una corriente dinámica de aire.

\section{RESULTADOS}

\subsection{Caracterización analítica de las soluciones}

Las concentraciones de las especies iónicas encontradas en las FAP se dan en la tabla 2, y su representación en función del tiempo en la Fig. 1 (a). A partir de los puntos de inflexión en las curvas a: 20 minutos, 3 horas y 1 día, es posible establecer los períodos cinéticos: pre-inducción (I), inducción o latente (II), aceleración (III) y deceleración (IV) respectivamente. El primer punto de la curva (20 minutos) corresponde a la solución obtenida después del amasado ( 3 minutos), centrifugado (10 minutos), y filtrado ( 7 minutos). Se debe mencionar que, entre 3 horas y 1 día, no se han obtenido resultados y que, probablemente, el final del período III tenga lugar antes de un día. Como se puede ver, a los 20 minutos después del amasado (periodo I), la solución ha alcanzado un valor de $\mathrm{pH}$ de 11,56, con unos niveles de concentración de calcio y aluminio (como especie iónica $\mathrm{Al}(\mathrm{OH})_{4}^{-}$de: $0,023 \mathrm{M}$ y $0,041 \mathrm{M}$ produced from the strongly exothermic hydration reaction. Before set, (up to three hours) solution was extracted by centrifugation and filtration of the samples in a $N_{2}$, atmosphere to avoid atmospheric carbonation. From one day, the poresolution was expressed by employing a device similar to that described by previous investigators $[19,20]$. The mechanical pressure applied was gradually increased up to reach a maximum value of $500 \mathrm{MPa}$.

The concentrations of sodium and potassium were determined by atomic absorption spectroscopy by means of a Perkin Elmer 305 equipment, after the correspondind dilutions were made, and those of calcium and aluminium by inductively coupled plasma (ICP) emission spectroscopy carried out with a Yobin Ybon $38 \mathrm{VHR}$. The $\mathrm{pH}$ was measured with a combined electrode for the $\mathrm{pH}$ range 0 -14. It has not been possible the measurements of $\mathrm{OH}^{-}$concentrations by direct titration against $\mathrm{HCl}$ due to the interference of aluminium hydroxide precipitation during the titration.

XRD patterns were recorded on a Philips $P W$ 1730 diffractometer using a graphite monochromator, and $C u K_{\alpha 1}$ radiation. TGA and DTA were conducted using a Mettler TA-1 analysis system. The weight of samples was 300 $\mathrm{mg}$, a heating rate of $4^{\circ} \mathrm{C} . \mathrm{min}^{-1}$ and air stream were employed.

\section{RESULTS}

\subsection{Analytical Characterization of the solutions}

The concentrations of ionic species found in the solutions are given in table 2 and represented as a function of time in Fig. 1 (a). From the inflection points on the curves at: 20 minutes, three hours and one day, it is possible to establish the kinetic periods: pre-induction (I), induction or latent (II), acceleration (III) and deceleration (IV) respectively. The first point of the curve (20 minutes) corresponds to the solution obtained after mixing (three minutes), centrifugation (ten minutes) and filtration (seven minutes). It should be mentioned that between three hours and one day no results have been taken and probably the end of period III takes place before one day. As can be seen, by 20 minutes after mixing (period I) the solution has reached a $\mathrm{pH}$ value of 11.56 with calcium and aluminium (as [Al(OH) ${ }_{4}$ ionic specie) concentration levels of $0.023 \mathrm{M}$ and $0.041 M$ respectively and those of sodium and 
TABLA 2 TABLE 2

Caracterización Química de las Fases Acuosas de los Poros (Chemical Characterization of Pore-solutions)

\begin{tabular}{|c|c|c|c|c|c|c|c|c|c|}
\hline$t$ & pH & $\begin{array}{c}\left|\mathrm{OH}^{-}\right| \\
(\mathrm{M})\end{array}$ & $\begin{array}{c}{\left[\mathrm{Ca}^{2+}\right]} \\
(\mathrm{M})\end{array}$ & $\begin{array}{l}{\left[\mathrm{AI}(\mathrm{OH})_{4}^{-}\right]} \\
\text {(M) }\end{array}$ & $\begin{array}{c}{\left[\mathrm{Na}^{+}\right]} \\
(\mathrm{M})\end{array}$ & $\begin{array}{l}{\left[K^{+}\right]} \\
(\mathbf{M})\end{array}$ & $\Sigma e q(+)$ & $\operatorname{\Sigma eq}(-)$ & $\begin{array}{l}I \\
(M)\end{array}$ \\
\hline $20 \mathrm{~min}$. & 11.56 & 0.0036 & 0.023 & 0.041 & 0.00015 & 0.0015 & 0.048 & 0.045 & 0.069 \\
\hline $45 \mathrm{~min}$. & 11.55 & 0.0035 & 0.023 & 0.044 & 0.0009 & 0.0020 & 0.049 & 0.047 & 0.071 \\
\hline $3 \mathrm{~h}$ & 11.51 & 0.0032 & 0.018 & 0.038 & 0.007 & 0.004 & 0.047 & 0.041 & 0.062 \\
\hline $1 d$ & 12.53 & 0.034 & 0.0005 & 0.065 & 0.040 & 0.065 & 0.11 & 0.10 & 0.10 \\
\hline $2 d$ & 12.67 & 0.047 & 0.0006 & 0.059 & 0.040 & 0.067 & 0.11 & 0.11 & 0.11 \\
\hline $7 d$ & 12.77 & 0.059 & 0.0003 & 0.081 & 0.047 & 0.086 & 0.13 & 0.14 & 0.14 \\
\hline $15 d$ & 12.66 & 0.046 & 0.0005 & 0.073 & 0.042 & 0.077 & 0.12 & 0.12 & 0.12 \\
\hline $30 \mathrm{~d}$ & 12.69 & 0.049 & 0.00002 & 0.084 & 0.045 & 0.085 & 0.13 & 0.13 & 0.13 \\
\hline
\end{tabular}

\section{Concentración (M)}

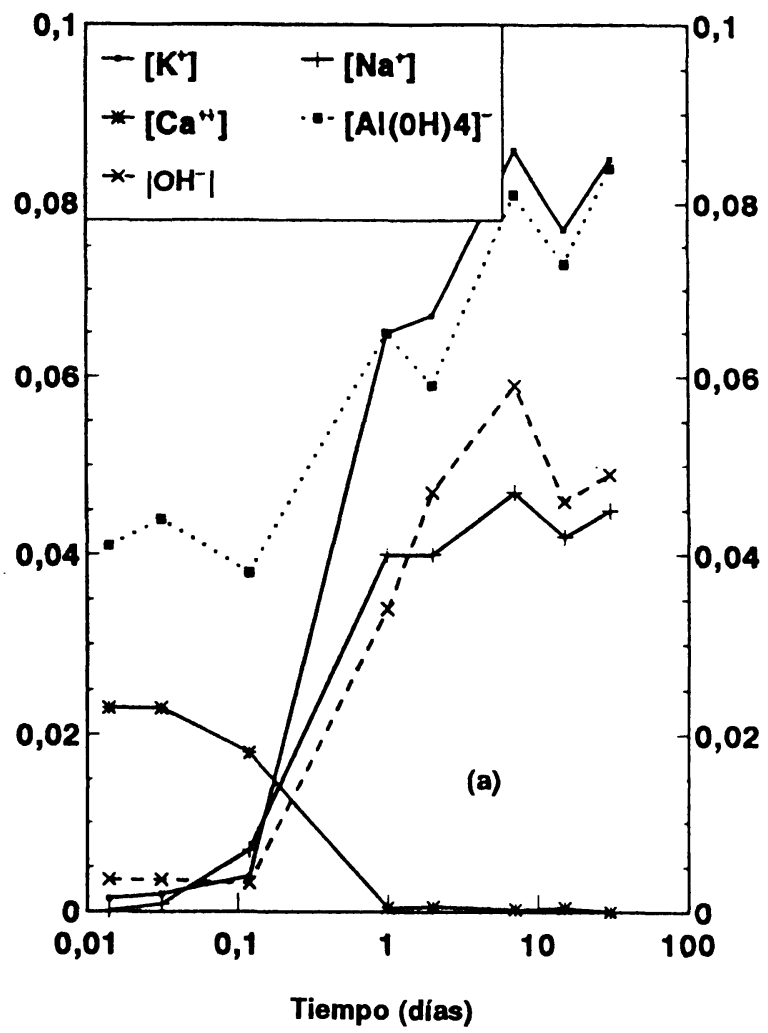

Concentración corregida (M)

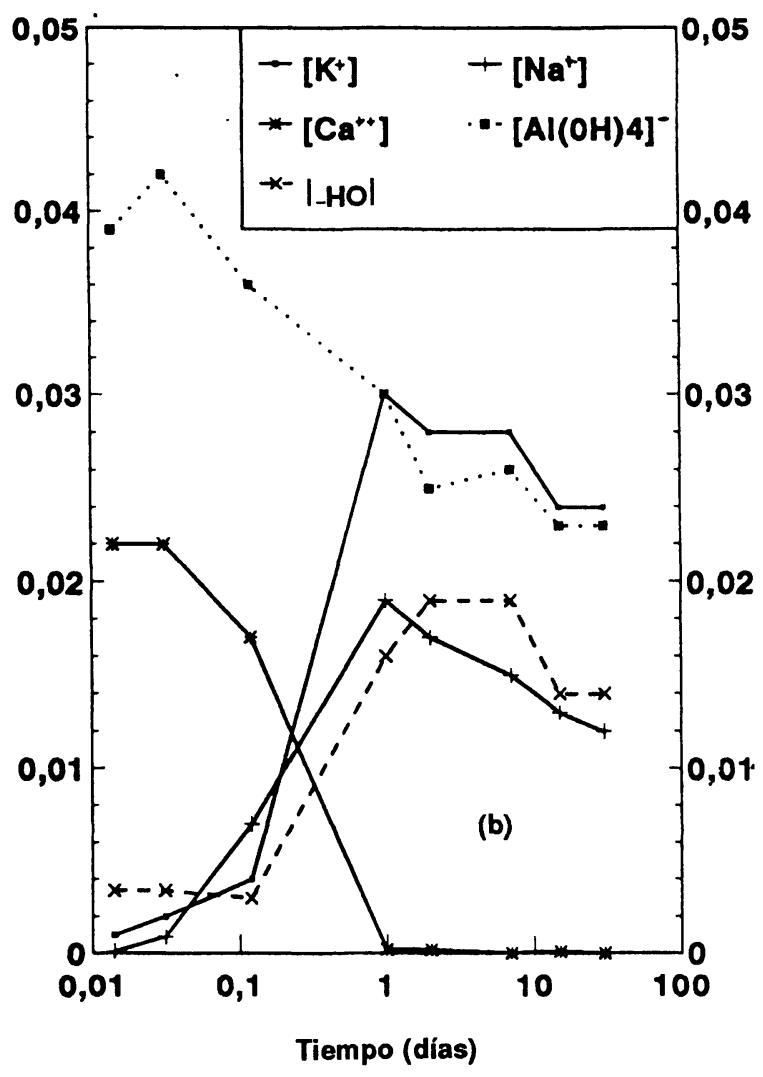

Fig. 1.-Variación de las Concentraciones lónicas de la Fase Acuosa de los Poros en Función del Tiempo.

Fig. 1. -Variation of Ionic Concentrations of the Poresolutions as a Function of Time. 
respectivamente y de sodio y potasio: $0.00015 \mathrm{M}$ y $0.0015 \mathrm{M}$ respectivamente. Entre 20 minutos y 3 horas (período II), se observa una disminución tanto de $\mathrm{Ca}^{2+}$ como de $\mathrm{Al}(\mathrm{OH})_{4}^{-}$, alcanzando sus concentraciones valores de $0,018 \mathrm{M}$ y $0,038 \mathrm{M}$ respectivamente. Por el contrario, $\mathrm{Na}^{+}$y $\mathrm{K}^{+}$ aumentan de $1,5 \times 10^{-4} \mathrm{M}$ a $7 \times 10^{-3} \mathrm{M}$ y de $1,5 \times 10^{-3} \mathrm{M}$ a $4 \times 10^{-3} \mathrm{M}$ respectivamente. El principal cambio en la composición de la FAP tiene lugar después de tres horas (período III). El calcio disminuye fuertemente mientras que las concentraciones del resto de los iones aumentan dramáticamente. Durante el período IV, en general, los valores oscilan en el tiempo; la composición de la FAP en este período corresponde a una mezcla de $\mathrm{KAl}(\mathrm{OH})_{4}$ y $\mathrm{NaOH}$. El balance de las concentraciones, equivalentes en cargas de los iones, nos permite deducir que no existen en la FAP más iones que los analizados (tabla 2).

\subsection{Factor de concentración de agua}

El volumen de agua de la solución de los poros no es constante a lo largo del tiempo de hidratación, disminuyendo bruscamente durante el período III, debido a la masiva precipitación de las nuevas fases hidratadas. Este cambio del volumen de la FAP influye en los datos de concentración de las especies iónicas, siendo necesario su corrección por medio de un factor de concentración. Los valores de concentración, así corregidos, permiten establecer el movimiento neto de los iones entre las fases sólida y acuosa $(20,22)$, asegurando que las variaciones de las concentraciones iónicas no se deben a diluciones o concentraciones del agua libre contenida en los poros (disolvente), sino a procesos de disoluciónprecipitación de las nuevas fases hidratadas. Esto es particularmente útil para conocer la evolución de los porcentajes de álcalis del cemento disueltos en la FAP a lo largo del tiempo.

En la tabla 3 se muestran los valores de los factores de concentración, así como las concentraciones iónicas corregidas. Los factores han sido calculados según propuso Diamond (22). Primeramente, el agua libre residual se obtiene a partir del agua combinada (pérdida de agua por calcinación de las muestras, previamente secadas en desecadores con gel de silice, hasta $1.000^{\circ} \mathrm{C}$ ); en segundo lugar, el factor se calcula dividiendo el agua libre original $(0,5 \mathrm{~g}$ por $\mathrm{g}$ de cemento 0 $50 \%$ ) por el agua libre residual (diferencia entre el agua libre original y la correspondiente combinada) previamente determinada, $y$, finalmente, los valores de concentración iónica, directamente medidos en las FAP (tabla 2), se dividen por los factores correspondientes.

Respecto a los períodos III y IV, el perfil de las curvas de las concentraciones corregidas

(Fig. 1 b) es bastante distinto, si los comparamos potassium: $1.5 \times 10^{-4} \mathrm{M}$ and $1.5 \times 10^{-3} \mathrm{M}$ respectively. Between 20 minutes and three hours (period II) a decrease of both $\mathrm{Ca}^{2+}$ and $\mathrm{Al}(\mathrm{OH})_{4}^{-}$is observed, ranging their concentration values from $0.023 \mathrm{M}$ to $0.018 \mathrm{M}$ and from $0.041 \mathrm{M}$ to $0.038 \mathrm{M}$ respectively. To the contrary, $\mathrm{Na}^{+}$and $\mathrm{K}^{+}$increase from $1.5 \times 10^{-4} \mathrm{M}$ to $7 \times 10^{3} \mathrm{M}$ and from $1.5 \times 10^{-4} M$ to $4 \times 10^{-3} M$ respectively. The main change of the composition of the solution takes place after three hours (period III). $\mathrm{Ca}^{2+}$ strongly decreases whereas the concentrations of the rest of ions dramatically increase. During the period $I V$, in general, the values oscilate increasing and decreasing over time. The composition of the pore-solution in this period corresponds to a mixture of $\mathrm{KAl}\left(\mathrm{OH}_{4}\right)$ and $\mathrm{NaOH}$. The balance of equivalent concentration in charges of the ions let one to deduce that another ions than those analyzed are not present in the solutions (see table 2).

\subsection{Water Concentration Factor}

The water volume of pore-solution is not constant over hydration time decreasing strongly during period (III) due to the massive precipitation of the new hydrated phases. This change of poresolution volume influences on the concentration data of the ionic species, being necessary their corrections by means of a water concentration factor. The so corrected concentration values allow to establish the net movement of the ions between solid and liquid phases $[20,22]$, and therefore it is possible to assure that the variations of ionic concentrations are not due to dilution or concentration of the free-water contained in the pores but to dissolutionprecipitation of the new hydrated phases. This is particularly useful to know the evolution of the percentage of cement alkalies dissolved in the pore-solution over time.

In table 3 the values of the concentration factors as well as the corrected ionic concentrations are shown. The factors have been calculated as Diamond proposed in a previous paper [22]. Firstly, the residual-free water is obtained from the bound-water (ignition loss of previously dried samples in desiccators with silica gel), secondly the factor is calculated by dividing the original free-water $(0.5 \mathrm{~g}$ per $\mathrm{g}$ of cement or $50 \%)$ by the residual-free-water (difference between the original fres-water and the corresponding boundwater), previously determined, and finally the ionic concentration values directly measured in the solutions (table 2) are dividing by the corresponding factors.

As far as the periods III and IV is concerning the profile of the curves of the evolutron of the corrected concentrations with time [Fig. 1 (b)] are 
(\%)

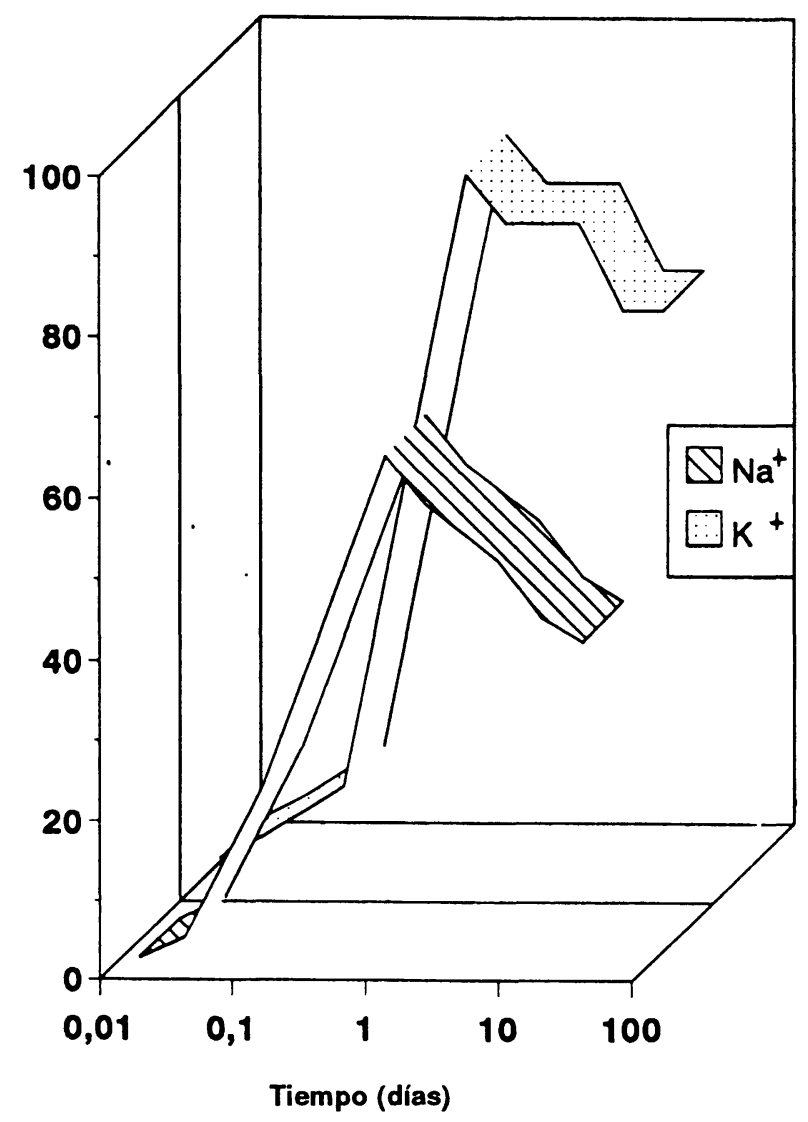

Fig. 2.-Porcentaje en lones Alcalinos $\mathrm{Na}^{+}$y $\mathrm{K}^{+}$encontrados en la Fase Acuosa de los Poros.

Fig. 2. Percentaje of Alkaline $\mathrm{Na}^{+}$y $\mathrm{K}^{+}$lons Found in the Pore-solution.

TABLA 3 TABLE 3

Concentraciones lónicas Corregidas mediante el Factor de Concentración de Agua (Ionic Cencentrations Corrected by the Water Concentration Factor)

\begin{tabular}{|c|c|c|c|c|c|c|c|}
\hline $\mathbf{t}$ & $\mathrm{pH}$ & $\begin{array}{c}\mathrm{OH}^{-} \mid \\
(\mathrm{M})\end{array}$ & $\begin{array}{c}{\left[\mathrm{Ca}^{2+}\right]} \\
(\mathrm{M})\end{array}$ & $\begin{array}{c}{\left[\mathrm{Al}(\mathrm{OH})_{4}^{-}\right]} \\
(\mathrm{M})\end{array}$ & $\begin{array}{c}\left.\mathrm{Na}^{+}\right] \\
(\mathrm{M})\end{array}$ & $\begin{array}{c}{\left[\mathrm{K}^{+}\right]} \\
(\mathrm{M})\end{array}$ & $\begin{array}{c}\text { Water } \\
\text { conc. } \\
\text { factor }\end{array}$ \\
\hline $20 \mathrm{~min}$. & 11.53 & 0.0034 & 0.022 & 0.039 & 0.0001 & 0.001 & 1.05 \\
$45 \mathrm{~min}$. & 11.53 & 0.0034 & 0.022 & 0.042 & 0.0009 & 0.002 & 1.04 \\
$3 \mathrm{~h}$ & 11.48 & 0.0030 & 0.017 & 0.036 & 0.007 & 0.004 & 1.06 \\
$1 \mathrm{~d}$ & 12.20 & 0.016 & 0.0002 & 0.030 & 0.019 & 0.030 & 2.14 \\
$2 \mathrm{~d}$ & 12.28 & 0.019 & 0.0002 & 0.025 & 0.017 & 0.028 & 2.40 \\
$7 \mathrm{~d}$ & 12.28 & 0.019 & 0.0001 & 0.026 & 0.015 & 0.028 & 3.12 \\
$15 \mathrm{~d}$ & 12.15 & 0.014 & 0.0001 & 0.023 & 0.013 & 0.024 & 3.22 \\
$30 \mathrm{~d}$ & 12.15 & 0.014 & 0.000005 & 0.023 & 0.012 & 0.024 & 3.60 \\
\hline
\end{tabular}


con los correspondientes a la figura 1 a. Como se puede ver, los iones aluminato y calcio disminuyen apreciablemente durante el período III, como resultado del proceso de precipitación, mientras que $\mathrm{OH}^{-}, \mathrm{Na}^{+}$y $\mathrm{K}^{+}$aumentan. Durante el período IV, el calcio ha desaparecido prácticamente; aluminato, sodio y potasio tienden a decrecer de forma lenta a partir del séptimo día, al igual que los valores de concentración de $\mathrm{OH}^{-}$.

El porcentaje de álcalis del cemento encontrado en la FAP aparece en la figura 2. Si el $100 \%$ de los álcalis del cemento estuvieran disueltos, las concentraciones en disolución para una relación $a / c=0,5$ serían de $0,030 \mathrm{M}$ y $0,034 \mathrm{M}$ respectivamente. A partir de estos valores, es posible calcular el porcentaje de álcalis de la FAP, dividiendo las concentraciones corregidas (tabla 3) por la cantidad total de álcalis. Como se puede ver en la figura 2, los valores de los porcentajes alcanzan un máximo a un día (88\% y $63 \%$ para $\mathrm{K}^{+}$y $\mathrm{Na}^{+}$respectivamente), decreciendo a lo largo del tiempo como ya se mencionó anteriormente.

\subsection{Análisis por DRX}

Los resultados de DRX de la PCAH a diferentes tiempos de la reacción de hidratación se muestran en la figura 3. La intensidad de los picos de difracción de los componentes del cemento anhidro ( $C A, C_{12} A_{7}$, y la fase ferrítica) desaparece progresivamente a medida que la hidratación avanza, mientras que aquéllos correspondientes a los nuevos aluminatos hidratados empiezan a aparecer al cabo de un dia (Fig. 3 b). Las fases hidratadas detectadas son: las dos variedades hexagonales $\mathrm{C}_{2} \mathrm{AH}_{8}$, $\mathrm{CAH}_{10}$ y la cúbica $\mathrm{C}_{3} \mathrm{AH}_{6}$ (patrones JPDS n. 11 $205,12-408$ y 24-217 respectivamente). Como puede verse, los picos de difracción de las fases hidratadas son anchos y de baja intensidad, lo cual parece indicar una pobre cristalinidad de los compuestos.

\section{DISCUSIÓN}

La cinética de hidratación del CAF y el aluminato monocálcico (CA), y particularmente el mecanismo que regula la disolución inicial y el período de inducción, han sido estudiados previamente por Barret y colaboradores $(9,10)$, así como por Fujii y colaboradores (18). De acuerdo con Fujii, durante el período de inducción, la solución permanece casi inalterable y es equilibrada temporalmente por partículas de CA hidratado superficialmente y gel de $\mathrm{Al}(\mathrm{OH})_{3}$, que se forma por disolución de iones $\mathrm{Al}(\mathrm{OH})_{4}{ }^{-}$. Cuando el espesor de la capa hidratada de partículas de CA alcanza un valor crítico, se origina su destrucción, generándose núcleos de compuestos hidratados; en este momento se quite different in comparison to those of fig. 1 (a). As can be seen, aluminate and calcium ions decrease appreciably during period III as a result of the precipitation process whereas $\mathrm{OH}^{-}, \mathrm{Na}^{+}$and $K^{+}$increase. During period IV, calcium has practically disappeared, aluminate, sodium and potassium tend slightly to decrease over time as well as $\mathrm{OH}^{5}$ values from seven days.

The percentage of cement alkalies found in the poresolution appears in Fig. 2. If the $100 \%$ of cement alkalies were dissolved, the solution concentration of $\mathrm{Na}^{+}$and $\mathrm{K}^{+}$ions would be $0.030 \mathrm{M}$ and $0.034 \mathrm{M}$ respectively, for the water/cement ratio of 0.5 employed. From these values it is possible to calculate the percentage of alkalies in the poresolution by dividing the corrected concentrations (see table 3) by the corresponding total amount of alkalies aforementioned. As can be seen in Fig. 2, the percentage values reach a maximum at one day (88\% and $63 \%$ for $\mathrm{K}^{+}$and $\mathrm{Na}^{+}$respectively), decreasing over time, as was earlier mentioned.

\subsection{XRD Analysis}

The XRD results of HACP at different hydration reaction times are shown in Fig. 3. The intensity of the $X$-ray reflections of ahydrous components (CA, $C_{12} A_{7}$ and Ferrite phase) progressively disappear as hydration advances whereas those corresponding to the new hydrated aluminates begin to appear at one day [Fig. 3 (b)]. The hydrated phases detected are: the two hexagonal varieties $\mathrm{C}_{2} A \mathrm{H}_{8}$ and $\mathrm{CAH}_{10}$ and the cubic-one $C_{3} A_{6} H_{6}$ (JPDS files $n .{ }^{9} 11-205,12-408$ and 24-217 respectively). As can be seen, the $X$-ray reflections of the hydrated phases are broads and low intenses which seems to indicate a poor crystallinity of the compounds.

\section{DISCUSSION}

The kinetic of hydration of HAC and monocalcium aluminate (CA) and particularly the mechanism which regulates the length of the initial dissolution and induction period have been previously studied by Barret and co-workers [9, 10] and Fujii and coworkers [18]. According to Fujii, during the induction period, the solution remains almost unchanged and is equilibrated temporaly with both superficially intrussion-hydrated CA particles and $\mathrm{Al}(\mathrm{OH})_{3} \mathrm{gel}$ formed by dissociation of $\mathrm{Al}(\mathrm{OH})_{4}^{-}$ ions. When the thickness of hydrated layer on the CA particles reaches a critical value, destruction occur and nuclei of hydrous compounds are generated, at this time the end of the induction period is produced. Subsequent reaction proceeds 


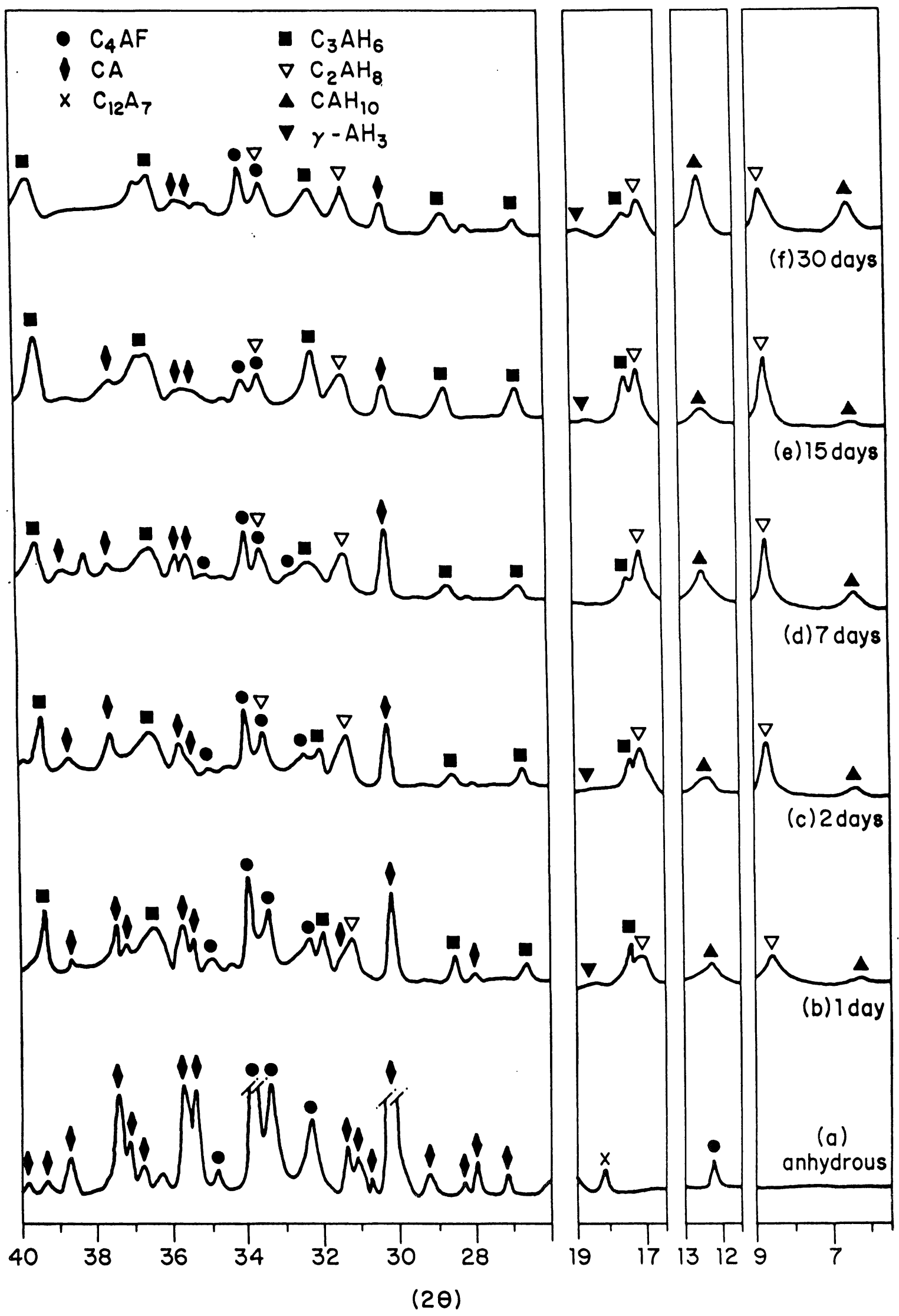

Fig. 3.-Evolución de los Diagramas de DRX de la PHCA en Función del Tiempo.

Fig. 3.-Evolution of the XRD Patterns of HACP as a Function of Time. 
produce el final del período de inducción. Las reacciones subsiguientes tienen lugar mediante mecanismos de disolución-cristalización, sobre las partículas de CA y no en la fase líquida.

Barret estableció que en contacto con el agua se produce la disolución de CA, aunque la relación $[\mathrm{CaO}] /\left[\mathrm{Al}_{2} \mathrm{O}_{3}\right]$ en solución es mayor que $1(1,07$ para CA puro y 1,14 para CAF Lafarge). Por otra parte, se constató una gran diferencia entre el producto de solubilidad experimental del CA y el calculado de acuerdo con la siguiente reacción:

$\mathrm{CaAl}_{2} \mathrm{O}_{4}+4 \mathrm{H}_{2} \mathrm{O} \rightarrow \mathrm{Ca}^{2+}+2 \mathrm{Al}(\mathrm{OH})_{4}^{-}$

Estas diferencias fueron atribuidas por los autores $(9,10)$ a la formación de una monocapa de $\mathrm{OH}^{-}$ adsorbida sobre los puntos aniónicos $\left(\mathrm{AlO}_{2}^{-}\right.$ y $\left.\mathrm{O}^{\prime}\right)$ localizados en la superficie de las partículas de CA (reacción directa en la interfase o proceso topoquímico entre las moléculas de agua y los oxi-iones). A continuación, la disolución se produce vía una secuencia repetitiva de formación de monocapas y disolución, de acuerdo con la siguiente reacción:

$$
\begin{aligned}
& \mathrm{CaAl}_{2} \mathrm{O}_{4}+4 \mathrm{H}_{2} \mathrm{O} \rightarrow\left(\mathrm{Ca}\left[\mathrm{Al}(\mathrm{OH})_{4}\right]_{2}\right)_{\mathrm{s}} \rightarrow \\
& \rightarrow \mathrm{Ca}^{2+}+2 \mathrm{Al}(\mathrm{OH})_{4}^{-}
\end{aligned}
$$

La precipitación de gel de $\mathrm{Al}(\mathrm{OH})_{3}$ se produce por disociación de iones $\mathrm{Al}(\mathrm{OH})_{4}^{-}$:

$\mathrm{Al}(\mathrm{OH})_{4}{ }^{-} \rightarrow \mathrm{OH}^{-}+\mathrm{Al}(\mathrm{OH})_{3}$

Por lo tanto, inmediatamente después de la disolución inicial, las partículas de CA se recubren de una capa hidratada de $\left(\mathrm{Ca}\left[\mathrm{Al}(\mathrm{OH})_{4}\right]_{2}\right)_{s}$ y gel de $\mathrm{Al}(\mathrm{OH})_{3}$ que actúan como un film protector que impide la hidratación. De esta manera, la composición de la fase acuosa permanece casi constante (período de inducción).

Los resultados aquí presentados están de acuerdo con los obtenidos previamente por los mencionados autores $(9,10,18)$. En contacto con el agua, los iones $\mathrm{Ca}^{2+}$ y $\mathrm{Al}(\mathrm{OH})_{4}^{-}$(junto con algunas trazas de $\mathrm{Na}^{+}$y $\mathrm{K}^{+}$) se disuelven alcanzando niveles de concentración de $0,023 \mathrm{M}$ y $0,04 \mathrm{M}$ respectivamente, $\left([\mathrm{CaO}] /\left[\mathrm{Al}_{2} \mathrm{O}_{3}\right]=1,12\right)$ y $\mathrm{pH}=11,56$. El correspondiente producto de solubilidad (disolución congruente) del CA es $10^{-4,99}$. Los coeficientes de actividad han sido calculados mediante la expresión de Debye-Hückel:

$\log \gamma=-0,507 z_{i}^{2}(\sqrt{1 / 1}+\sqrt{1})+0,21$

donde: $z$ es la carga del ión e I es la fuerza iónica de la solución.

El valor del producto de solubilidad termodinámico $\left(10^{-4,99}\right)$ está en concordancia con el obtenido por by dissolution-crystallization mechanisms on the CA particles, and not in the liquid phase.

Barret established that in contact with water the congruent dissolution of CA is produced although the $[\mathrm{CaO}] /\left[\mathrm{Al}_{2} \mathrm{O}_{3}\right]$ ratio in solution was higher than 1 (1.07 for pure CA and 1.14 for HAC Fondy Lafarge). On the other hand, it was constated a large difference between the experimental solubility product of $C A$ and the calculated one for the following reaction:

$\mathrm{CaAl}_{2} \mathrm{O}_{4}+4 \mathrm{H}_{2} \mathrm{O} \rightarrow \mathrm{Ca}^{2+}+2 \mathrm{Al}(\mathrm{OH})_{4}^{-}$

These differences were attributed by the authors $[9,10]$ to the formation of a monolayer of $\mathrm{OH}^{-}$ adsorbed on the $\mathrm{AlO}_{2}^{-}$and $\mathrm{O}^{-}$sites located at the surface of the CA particles (direct interface reaction or topochemic process between the water molecules and the oxy-ions). Thereafter, the dissolution is produced via a repetitive sequence of monolayer formation and dissolution according to the following reaction:

$$
\begin{aligned}
& \mathrm{CaAl}_{2} \mathrm{O}_{4}+4 \mathrm{H}_{2} \mathrm{O} \rightarrow\left(\mathrm{Ca}\left[\mathrm{Al}(\mathrm{OH})_{4}\right]_{2}\right)_{s} \rightarrow \\
& \rightarrow \mathrm{Ca}^{2+}+2 \mathrm{Al}(\mathrm{OH})_{4}^{-}
\end{aligned}
$$

The precipitation of $\mathrm{Al}(\mathrm{OH})_{3}$ gel is produced by dissociation of $\mathrm{Al}(\mathrm{OH})_{4}{ }^{-}$ions:

$\mathrm{Al}(\mathrm{OH})_{4}^{-} \rightarrow \mathrm{OH}^{-}+\mathrm{Al}(\mathrm{OH})_{3}$

Therefore, immediately afther the initial dissolution, CA particles are covered on the surface by a hydrated layer $\left(\mathrm{Ca}\left[\mathrm{Al} /(\mathrm{OH})_{4}\right]_{2}\right)_{s}$ and Al) $\mathrm{OH})_{3}$ gel which act as a protector film stopping the hydration. So, the solution remains almost unchanged (induction period).

The results herein presented agree farewell with those obtained previously by the aforementioned authors $[9,10,18]$. In contact with water, $\mathrm{Ca}^{2+}$ and $\mathrm{Al}(\mathrm{OH})_{4}^{-}$ions (together with some traces of $\mathrm{Na}^{+}$and $\mathrm{K}^{+}$) are dissolved reaching a concentration of $0.023 \mathrm{M}$ and $0.041 \mathrm{M}$ respectively ([CaO $]\left[\left[\mathrm{Al}_{2} \mathrm{O}_{3}\right]=1.12\right)$ and $\mathrm{pH}=11.56$. The corresponding solubility product (congruent dissolution) of $C A$ is: $10^{-4.99}$. The activity coefficients have been calculated by the extended Debye-Hückel expression:

$\log \gamma=-0,507 z_{i}^{2}(\sqrt{1 / 1}+\sqrt{1})+0,21$

where: $z$ is the charge of the ion and $I$ is the ionic strength of the solution.

The value of thermodynamic solubility product $\left(10^{-4.99}\right)$ is in concordance with that obtained by 
Barret para la reacción (1): $10^{-5,18}$ ó Fujii $10^{-4,97}$, y es muy diferente al producto de solubilidad calculado $\left(k=10^{-2,7}\right.$ ó $\left.10^{2,45}\right)$ a partir de los valores de entalpía libre estándar $\left(\Delta \mathrm{G}^{\circ}\right)$. El $\mathrm{pH}$ de la solución $(11,56)$ parece indicar que la reacción (3) se está produciendo con la precipitación del gel de $\mathrm{Al}(\mathrm{OH})_{3}$. Por lo tanto, sobre la base de estos resultados se puede deducir que el mecanismo de hidratación inicial del CAF es como el del (CA) aluminato monocálcico. La precipitación del gel de $\mathrm{Al}(\mathrm{OH})_{3}$ se confirma tanto desde el punto de vista termodinámico como a partir del contenido de agua combinada (2\%).

El período de inducción o latente (II) es muy importante en relación al mecanismo de fraguado del cemento. La composición de la fase acuosa y los primitivos núcleos de precipitados formados en este período, regulan el desarrollo de la nueva matriz sólida hidratada. La duración de este período depende de muchos factores tales como: relación a/c, temperatura, presencia de aditivos, tiempo de amasado y tipo de probetas (cantidad de masa por unidad de área externa) (12-17). Por ejemplo, el período latente no ha sido encontrado para un CAF (Lafarge) cuando se amasa con una relación $\mathrm{a} / \mathrm{c}=10$ [9]. En este trabajo, este período se alarga a 3 horas, durante el cual la composición de la fase acuosa no es constante, decreciendo las concentraciones de calcio y aluminio hasta un valor de relación C/A de 0,95 (Fig. 5) y aumentando el agua combinada hasta un $3 \%$. Estos resultados muestran que están teniendo lugar procesos de precipitación y, además, que el período de inducción es, de hecho, un período de "pseudo-inducción" durante el cual la fase acuosa está sobresaturada respecto a la solubilidad de las posibles fases hidratadas que pueden precipitar:

$$
\begin{aligned}
& \mathrm{C}_{3} \mathrm{AH}_{6} \rightarrow 3 \mathrm{Ca}^{2+}+2 \mathrm{Al}(\mathrm{OH})_{4}^{-}+4 \mathrm{OH}^{-} \\
& \mathrm{C}_{2} \mathrm{AH}_{8} \rightarrow 3 \mathrm{Ca}^{2+}+2 \mathrm{Al}(\mathrm{OH})_{4}^{-}+2 \mathrm{OH}^{-}+3 \mathrm{H}_{2} \mathrm{O} \\
& \mathrm{CAH}_{10} \rightarrow \mathrm{Ca}^{2+}+2 \mathrm{Al}(\mathrm{OH})_{4}^{-}+6 \mathrm{H}_{2} \mathrm{O}
\end{aligned}
$$

A partir de tres horas (período de aceleración), se produce una gran nucleación y precipitación de las anteriormente mencionadas fases hidratadas (ver DRX). Los cambios más relevantes en la composición de la FAP son la disminución de la relación [CaO]/[ $\left.\mathrm{Al}_{2} \mathrm{O}_{3}\right]$ (Fig. 5) y el brusco aumento tanto de los iones $\mathrm{Na}^{+}$y $\mathrm{K}^{+}$como del $\mathrm{pH}$, el cual alcanza un valor de 12,77 . Este alto $\mathrm{pH}$ es debido a la solubilización de una parte de los álcalis del cemento (un $80 \%$ de $\mathrm{K}^{+}$y $63 \%$ de $\mathrm{Na}^{+}$), así como al descenso de volumen de agua libre disponible en los poros.

Desde un punto de vista termodinámico, los diferentes hidratos detectados por DRX (Fig. 3) $\mathrm{C}_{3} \mathrm{AH}_{6}, \mathrm{C}_{2} \mathrm{AH}_{8}$ y $\mathrm{CAH}_{10}$ precipitarían no de forma simultánea, sino fraccionadamente debido a la diferencia de órdenes de magnitud en sus
Barret for reaction (1): $10^{-5.18}$ or Fujii: $10^{-4.97}$, and very different to that of calculated solubility product $\left(K=10^{-2.71}\right.$ or $\left.10^{2.45}\right)$ from the free standard enthalpy values $\left(\Delta G_{f}^{\circ}\right)$. The $\mathrm{pH}$ of the solution (11.56) seems to indicate that the reaction (2) with precipitation of $\mathrm{Al}(\mathrm{OH})_{3} \mathrm{gel}$ is being produced. Therefore, on the basis of these results it may be deduced that the mechanism of initial hydration of HAC is like that of monocalcium aluminate. The precipitation of $\mathrm{Al}(\mathrm{OH})_{3} \mathrm{gel}$ is confirmed from the thermodynamic point of view as well as from the bound-water content (2\%).

The induction or latent period (II) is very important in relation to the mechanism of cement setting. The composition of the solution and the primitive nuclei of precipitates formed in this period regulates the development of the new hydrated solid matrix. The length of this period depends on the many factors such as: water/cement ratio, temperature, presence of additives and of mixing and placement [12-17]. For instance, latent period has not been found for a HAC (Fondu Lafarge) when a water/cement ratio of 10 is employed [9]. In the present work this period is as long as three hours in which the composition of the solution is not constant decreasing calcium and aluminate concentrations up to a C/A ratio value of 0.95 (see Fig. 5) and increasing the bound-water from $2 \%$ to $3 \%$. These results show that some precipitation process takes place and therefore the induction period is in fact a "pseudo-inductionperiod" in which the solution is supersaturated to respect the solubility of the possible hydrated phases to be precipitated:

$$
\begin{aligned}
& \mathrm{C}_{3} \mathrm{AH}_{6} \rightarrow 3 \mathrm{Ca}^{2+}+2 \mathrm{Al}(\mathrm{OH})_{4}^{-}+4 \mathrm{OH} \\
& \mathrm{C}_{2} \mathrm{AH}_{8} \rightarrow 3 \mathrm{Ca}^{2+}+2 \mathrm{Al}(\mathrm{OH})_{4}^{-}+2 \mathrm{OH}^{-}+3 \mathrm{H}_{2} \mathrm{O} \\
& \mathrm{CAH}_{10} \rightarrow \mathrm{Ca}^{2+}+2 \mathrm{Al}(\mathrm{OH})_{4}^{-}+6 \mathrm{H}_{2} \mathrm{O}
\end{aligned}
$$

From three hours (acceleration period), the massive nucleation and precipitation of the aforementioned hydrated phases is produced as was constated from XRD data (Fig. 3). As far as the composition of the pore solution is concerning, the more relevant changes are the decrease of $[\mathrm{CaO}]\left[\mathrm{Al}_{2} \mathrm{O}_{3}\right]$ ratio (see Fig. 5) and the strongly increase of both $\mathrm{Na}^{+}$and $\mathrm{K}^{+}$alkaline ions and $\mathrm{pH}$, which reaches a value of 12.77. This high $\mathrm{pH}$ is due to the solubilization of a part of the cement alkalies ( $80 \% \mathrm{~K}^{+}$and $63 \% \mathrm{Na}^{+}$) as well as the decrease of freewater available in the pores.

From a thermodynamic point of view, the different hydrates detected from XRD data (fig. 3): $C_{3} A H_{6}$, $\mathrm{C}_{2} A \mathrm{H}_{8}$ and $\mathrm{CAH}_{10}$ are not simultaneously but fractionaly precipitated due to the differences of magnitude of their solubility product constants: 


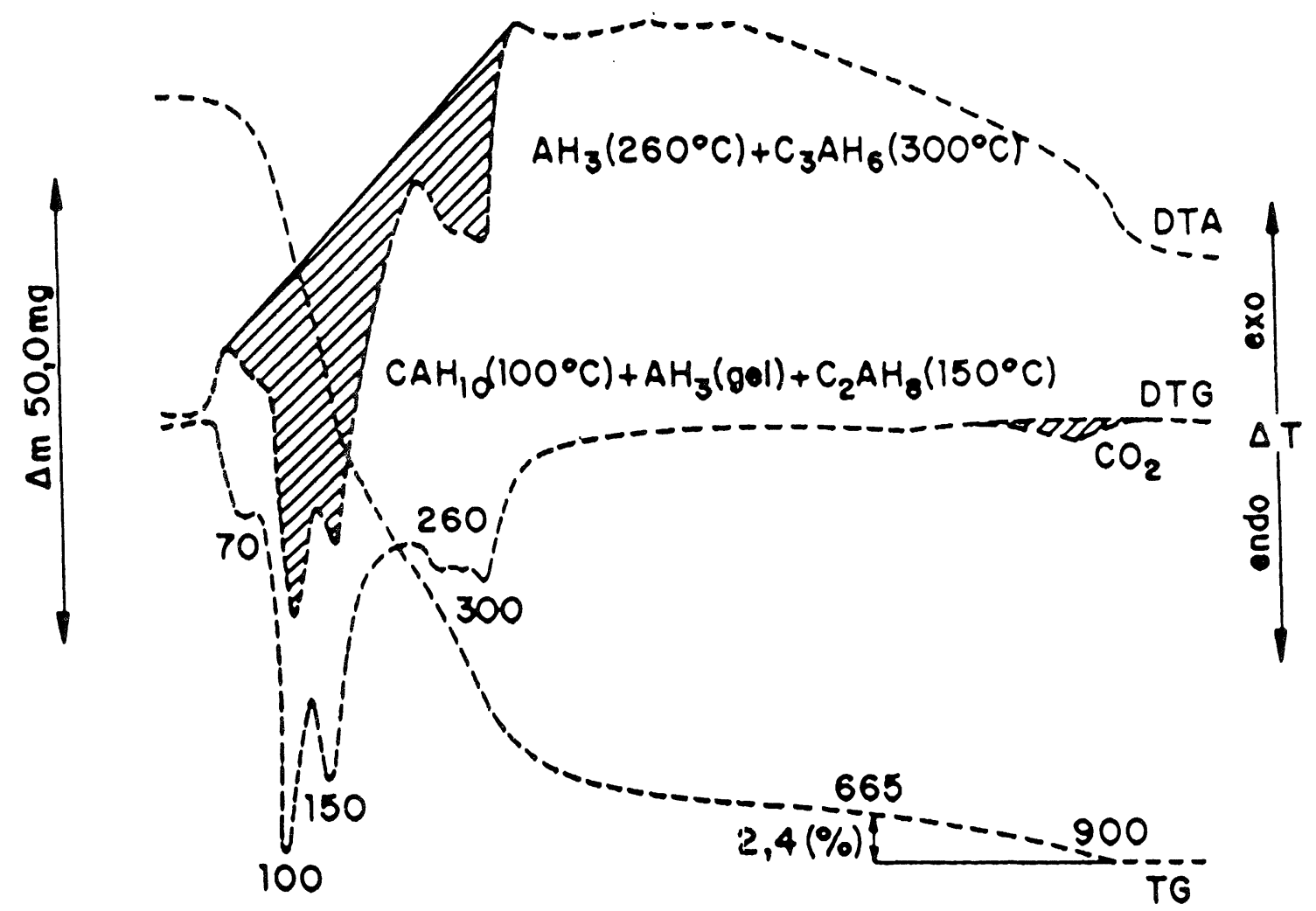

(b) 30 dias

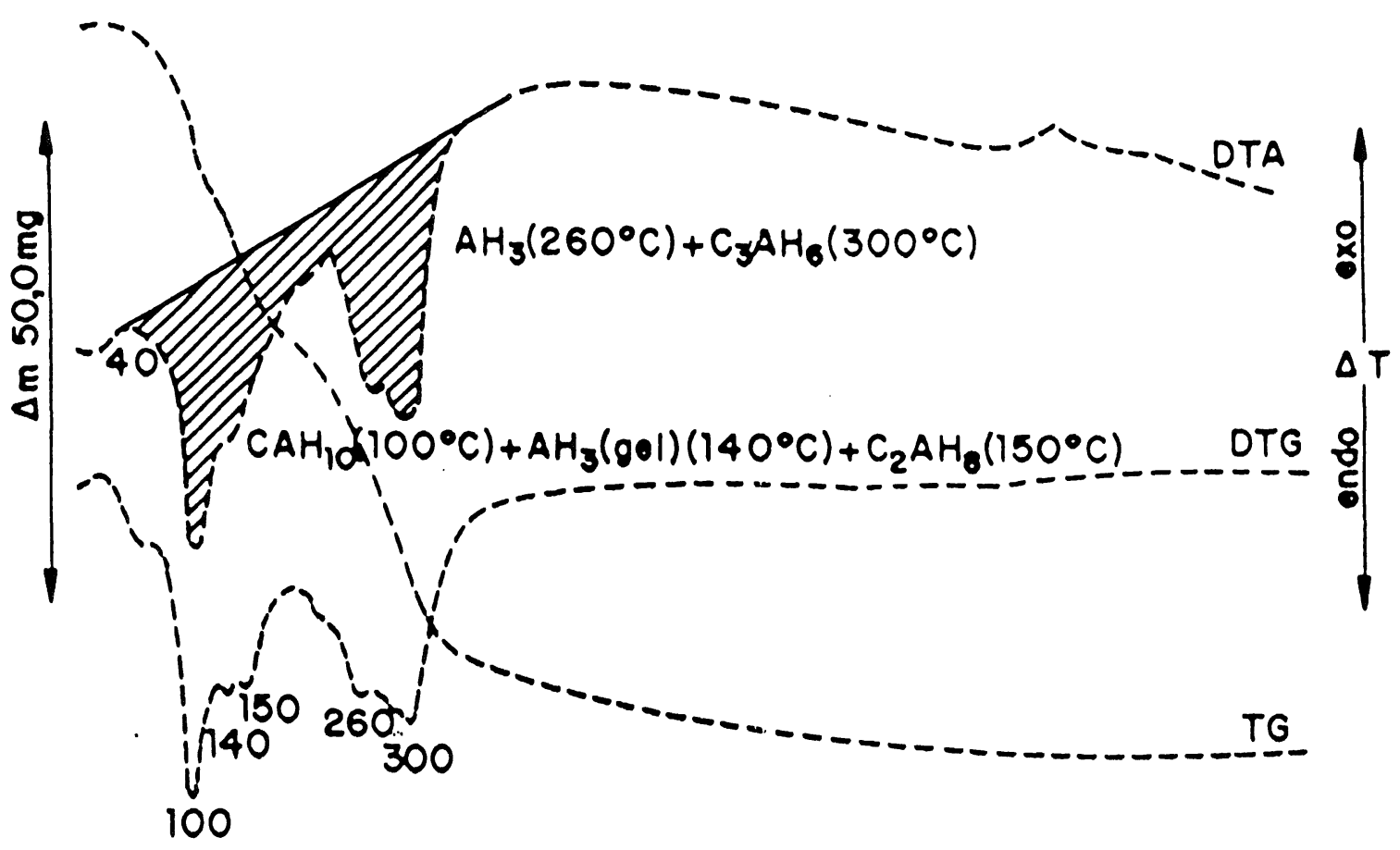

(a) 15 dias

Fig. 4.-Análisis Térmico de la PHCA.

Fig. 4. - Thermal Analysis of the HACP. 
constantes de productos de solubilidad: $10^{-22,3}$, $10^{-13,8}$ y $10^{-7,6}$ respectivamente (23). Así, primeramente precipitaría la variedad cúbica $\left(\mathrm{C}_{3} \mathrm{AH}_{6}\right)$ e inmediatamente después las hexagonales $\left(\mathrm{C}_{2} \mathrm{AH}_{8}\right.$ y $\left.\mathrm{CAH}_{10}\right)$.
$10^{-22.3}, 10^{-13.8}$ and $10^{-7.6}$ respectively [23]. So,

firstly will precipitate the cubic variety $\left(\mathrm{C}_{3} A \mathrm{H}_{6}\right)$ and inmediately after the hexagonal-ones $\left(\mathrm{C}_{2} A \mathrm{H}_{8}\right.$ and $\mathrm{CAH}_{10}$ ).

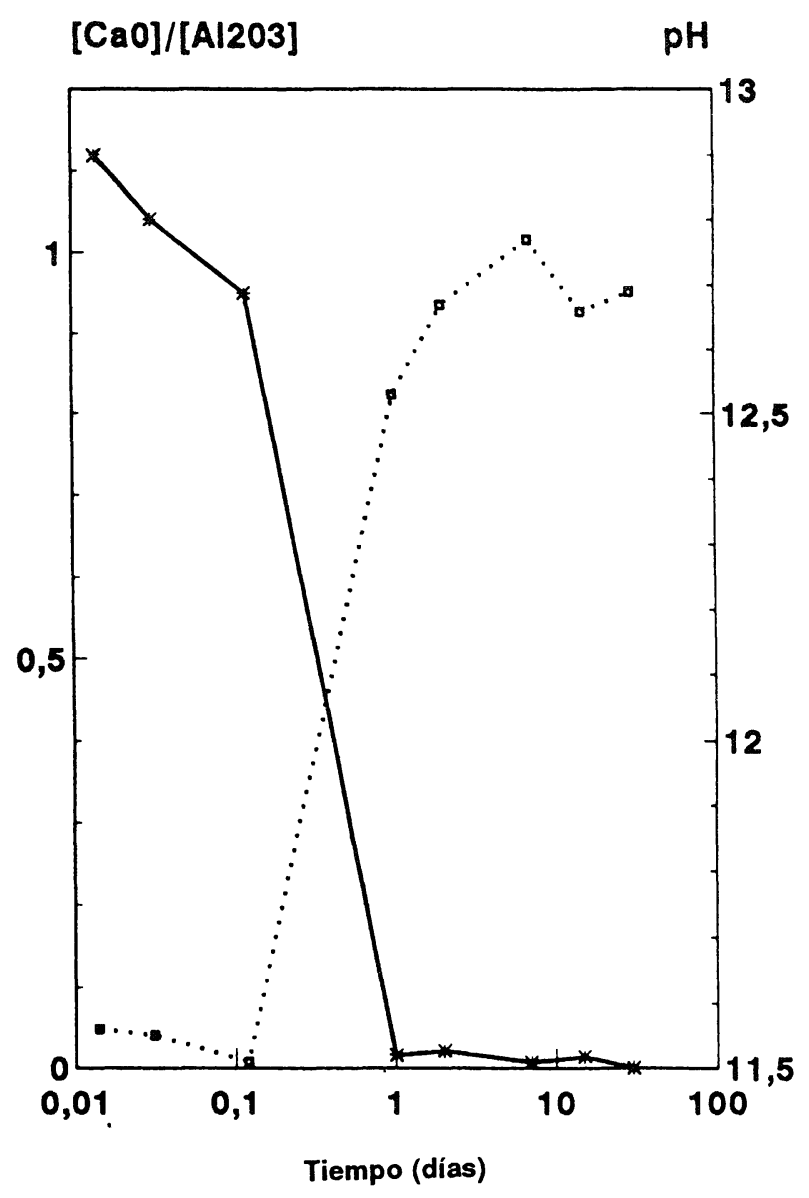

Fig. 5.-Evolución del pH y $[\mathrm{CaO}] /\left[\mathrm{Al}_{2} / \mathrm{O}_{3}\right]$ con el tiempo.

Fig.. 5.-Evolution of $\mathrm{pH}$ and $[\mathrm{CaO}] /\left[\mathrm{Al}_{2} / \mathrm{O}_{3}\right]$ with time.

Aunque los equilibrios de solubilidad de las reacciones [5], [6] y [7] se alcanzan durante el período IV, la composición tanto de la FAP como de las fases sólidas, no es constante a lo largo del mismo, lo que indica que procesos de disolución-precipitación se están produciendo, probablemente provocados por la disponibilidad de volumen de agua libre en el interior de los poros y la absorción-desorción de los álcalis (Fig. 2).

Finalmente, hay que destacar una ligera carbonatación de las muestras a lo largo del tiempo, puesta en evidencia a partir de los análisis térmicos (TG y ATD) que se muestran en la figura 4. Como se puede ver, a los 30 días (Fig. 4 b), entre $665^{\circ} \mathrm{C}$ y $900^{\circ} \mathrm{C}$, aparece una pérdida de peso en las curvas TG, típica del desprendimiento de $\mathrm{CO}_{2}$ que procede de la descomposición del $\mathrm{CaCO}_{3}$ amorfo o de carboaluminatos. Además, la disminución de la
Although the solubility equilibria of reactions [5], [6] and [7] are reached during period IV, nevertheless the composition of both poresolutions and solid phases is not constant over this period what indicates that dissolutionprecipitation processes are being produced probably provoked by the availability of the freewater volume within the pores and the adsorptiondesorption of alkalines (see Fig. 2).

Lastly, it should be mentioned that carbonation of the samples is produced over time what has been verified from TGA analysis showed in Fig. 4. As can be seen, at 30 days [Fig. 4 (b)], between $665^{\circ} \mathrm{C}$ and $900^{\circ} \mathrm{C}$ a weight loss appears on the TG curve, typical of the $\mathrm{CO}_{2}$ releases from amorphous $\mathrm{CaCO}_{3}$ or carboaluminate decomposition, besides the decrease of cubic $C_{3} A H_{6}$ is clearly confirmed from its DTA curve in which the height of the endothermic peak 
fase cúbica $\left(\mathrm{C}_{3} \mathrm{AH}_{6}\right)$ se confirma claramente en la curva de DTA, en la que la altura del pico endotérmico centrado a $300^{\circ} \mathrm{C}$ (deshidratación del $\mathrm{C}_{3} \mathrm{AH}_{6}$ ) es menor que la correspondiente en la muestra de quince días (Fig. 4 a). Esta carbonatación parcial de las muestras podría ser la causa de la disminución del pH y del contenido en álcalis de la FAP a lo largo del período IV.

\section{CONCLUSIONES}

De los datos obtenidos en el presente trabajo se pueden deducir las siguientes conclusiones:

La composición de la fase acuosa inmediatamente después del amasado es regulada por la solubilidad congruente del compuesto CA, alcanzándose valores de la relación $\mathrm{C} / \mathrm{A}$ de 1,12 y $\mathrm{pH}$ de 11,50.

El período de inducción tiene una duración de 3 horas, durante el cual la composición la fase acuosa no es constante, decreciendo el valor de la relación C/A hasta un valor de 0,95 y el pH a 11,51. Por lo tanto, este período cinético es, de hecho, un período "pseudo latente", durante el cual se produce cierta nucleación y precipitación de fases sólidas hidratadas. Los principales cambios en la composición de la fase acuosa tienen lugar durante el período III, donde se produce la gran precipitación de los nuevos aluminatos hidratados, aumentando bruscamente el $\mathrm{pH}$ y la concentración de $\mathrm{Na}^{+}$y $\mathrm{K}^{+}$, mientras que la concentración de $\mathrm{Ca}^{2+}$ y $\mathrm{Al}(\mathrm{OH})_{4}{ }^{-}$ disminuye. Durante el período IV, la estequiometría de la FAP corresponde a una mezcla de hidroxi-aluminato potásico y sosa [KAl(OH) y $\mathrm{NaOH}$ ], con intervalos de valores de $\mathrm{pH}$ oscilando entre 12,53 y 12,77 .

La variedad cúbica $\left(\mathrm{C}_{3} \mathrm{AH}_{6}\right)$ se carbonata a lo largo del tiempo. Este proceso podría explicar los cambios de composición de la FAP durante el período IV.

\section{AGRADECIMIENTOS}

Los autores muestran su agradecimiento a la DCYCIT por la financiación del trabajo y a Cementos Molins por los materiales suministrados, así mismo a las Dras. Gómez del Río y Andrade por los comentarios sobre el trabajo. centered at $300^{\circ} \mathrm{C}$ (dehydration of $\mathrm{C}_{3} \mathrm{~A} \mathrm{H}_{6}$ ) is lower than that of the sample at 15 days [fig. 4 (a)]. This partial carbonation of samples could be the cause of the decrease of $\mathrm{pH}$ and alkaline content of poresolution over period IV.

\section{CONCLUSIONS}

From data obtained in the present study the following conclusions may be deduced:

The composition of the solution inmediately after mixing is regulated by the congruent solubility of the $C A$ compound which produces a $C / A$ ratio value of 1.12 and $\mathrm{pH}$ of 11.56 .

The induction period is as long as three hours in which the composition of the solution is not constant decreasing the C/A value up to 0.95 and that of $\mathrm{pH}$ up to 11.51. Therefore this kinetic period is in fact a "pseudo-latent" period in which some nucleation and precipitation is produced. The main changes in the composition of the solutions take place during period III when the massive precipitation of the new hydrated aluminates is produced, increasing strongly the $\mathrm{pH}$ and alkaline $\mathrm{Na}^{+}$and $\mathrm{K}^{+}$concentrations whereas those of $\mathrm{Ca}^{2+}$ and $\mathrm{Al}(\mathrm{OH})_{4}^{-}$decrease. During period IV the stoichiometry of the poresolution is that of potassium aluminium hydroxide [ $\mathrm{KAl}(\mathrm{OH})_{4}$ ] and $\mathrm{NaOH}$ with $\mathrm{pH}$ values ranging from 12.53 to 12.77 .

The cubic variety $\left(\mathrm{C}_{3} A H_{6}\right)$ is carbonated over time. This process could explain the changes of the pore-solution composition during period IV.

\section{ACKNOWLEDGEMENTS}

The authors gratefully acknowledge to DGYCIT by the finantial suport and to Cements Molins for the material supplied as well as to Dras. Gómez del Rio and Andrade for the comments on the work.

\section{REFERENCIAS}

\section{REFERENCES}

[1] H. E. Schwite and U. Ludwing, in: Proc. 5th Intern. Symp. on the Chemistry of Cement, Tokio, 1968, p. 37.

[2] G. Sandran and B. Cottin, in: the same Symposium, p. 84.

[3] P. K. Mehta, in: the same Symposium, p. 148. 
[4] T. Vázquez, F. Triviño and A. Ruiz de Gauna, Mater. Constr., 158 (1975) 5.

[5] T. Vázquez, F. Triviño and A. Ruiz de Gauna, Mater. Constr. 157 (1975) 46.

[6] C. Bradbury, P. M. Callaway and D. D. Double, Mater. Sci. Eng., 23 (1) (1976) 43.

[7] D. C. Teychenné, Magaz. of Concr. Res., 27 (1975) 78.

[8] R. J. Collins and W. Gutt, BRE Information IP 8/88 (1988).

[9] P. Barret, D. Ménétier et D. Bertrandie, Cem. Concr. Res., 4 (1974) 545.

[10] D. Bertrandie et P. Barret, in: Proc. 8th Intern. Symp. on the Chemistry of Cement, Rio de Janeiro, 1986, p. 79.

[11] P. Barret and D. Bertrandies, in: Proc. 7th Intern. Symp. on the Chemistry of Cement, Paris, 1980, p. V-134.

[12] A. Capmas and C. Ménétrier, in: Proc. Conf. on Global Advances in Ferractories, ed. L. J. Trostel, (Amer. Ceram. Soc. Westerwille, $\mathrm{OH}$, USA, 1989), p. 1.157.

[13] B. R. Currel, R. Grzeskowiak, H. G. Midgley and J. R. Parsonage, Cem. Concr. Res., 17 (3) (1987) 420.

[14] S. M. Bushnell-Watson and J. H. Sharp, Cem. Concr. Res., 16 (1986) 975.

[15] S. A. Rodger and D. D. Double, Cem. Concr. Res., 14 (1984) 73.

[16] R. N. Edmonds and A. J. Majumdar, Cem. Concr. Res., 18 (1988) 473.

[17] P. Galtier and B. Guilhot, Cem. Concr. Res., 14 (1984) 679.

[18] K. Fuji, W. Kondo and H. Ueno, J. Amer. Ceram. Soc., 69 (4) (1986) 361.

[19] P. Longuet, L. Burglen and A. Zelwer, Rev. Mater. Constr, 676 (1973) 35.

[20] R. S. Barneyback and S. Diamond, Cem. Concr. Res, 11 (1981) 279.

[21] H. F. W. Taylor, in: Microstructure development during hydration of cements, eds. L. J. Strublle and P. W. Brown, Vol. 85 p. 47.

[22] S. Diamond, Cem. Concr. Res., 11 (1981) 383.

[23] W. F. W. Taylor, Cement Chemistry, (Academic Press, London, 1990) p. 323.

Próxima aparición del libro:

\section{JORNADAS SOBRE CEMENTO ALUMINOSO}

Publicación sobre las Jornadas que tuvieron lugar en el ICCET, durante los días 4 y 5 de junio de 1992, con la colaboración del Instituto Español del Cemento y sus Aplicaciones (IECA).

En este libro se recogen todas las intervenciones manifestadas, así como las conferencias impartidas.

El número de ejemplares, será limitado y se podrán adquirir en el Instituto Eduardo Torroja. 